\title{
ADSORPTION OF PHENOLS FROM OLIVE OIL MILL WASTEWATER AS WELL AS N AND P FROM A SIMULATED CITY WASTEWATER LIQUID ON ACTIVATED GREEK LIGNITES
}

\author{
Papanicolaou, C. ${ }^{1}$, Triantafyllou, G. ${ }^{2}$, Pasadakis, N. ${ }^{2}$, Foscolos, A, E. ${ }^{2}$ \\ ${ }^{1}$ Institute of Geology and Mineral Exploration, 3rd Entrance Olympic Village, Acharnai, 13677 Greece \\ ${ }^{2}$ Department of Mineral Resources Engineering, Technical Univ. of Crete, Akrotiri, Chania 73100
}

\begin{abstract}
Organic petrology and detailed physicochemical properties has been undertaken on twenty six Greek low rank coals (peat, peaty lignites, lignites of both matrix and xylite-rich lithotypes, and sub-bituminous coals in order to evaluate the increase of their adsorptive surface area by pyrolysis.

The results show that surface area of activated coal samples increased substantially and in some more than the commercial one. The increase in surface area was higher the higher the carbon content and the lower the ash content.

The adsorption capacity of phenols and the decrease of COD (Chemical Oxygen Demand) in olive oil mil wastewater disposals were measured in selected samples as well as the decrease of COD and the adsorption of nitrogen and phosphorus from a solution which simulates city waste disposals were measured in 14 selected Greek lignites and 1 commercially available activated lignite sample (HOK).

The maximum recorded adsorption of phenol was $30.6 \mathrm{mg} / \mathrm{g}$ of activated lignite while the commercial one (HOK) adsorbed $16 \mathrm{mg} / \mathrm{g}$ of activated lignite. The COD reduction was $1262 \mathrm{mg}$ of COD/g of activated lignite while in the commercial one the reduction was $439 \mathrm{mg}$ of COD/g of activated lignite. The maximum adsorption of $N$ and $P$ from the simulated city waste liquid was $6.41 \mathrm{mg} / \mathrm{g}$ of activated lignite and $2.52 \mathrm{mg} / \mathrm{g}$ of activated lignite, respectively. while the commercial one (HOK) adsorbed $2.84 \mathrm{mg} / \mathrm{g}$ and $2.42 \mathrm{mg} / \mathrm{g}$, respectively. Finally, the COD reduction was $50.28 \mathrm{mg} / \mathrm{g}$ of activated lignite and $34.92 \mathrm{mg} / \mathrm{g}$ for the commercially one (HOK).

The results show that Greek activated lignites can be used successfully for cleaning industrial and city wastes. These findings open the door for the economic exploitation of small to medium size lignite deposits in Greece, which are widespread in Greece.
\end{abstract}

Key words: Activated lignite, adsorption, olive oil mill wastes, city waste liquids.

\section{Introduction}

Research on activated lignite started some thirty five years ago (Fraser, 1972) while its application for environmental purposes started fifteen years later (Klose and Heschel, 1987) and continuous to date (Navarro et al., 2006). Activated lignite is used in the treatment of waste water (Engelhard and Lenz, 1997; Olson and Stepan, 2000; Stepan et al., 2001) and industrial wastes (Khan et al., 1981; Allen et al., 1997; Dabrowski et al., 2005; Galanakis et al., 2006). 
Table 1. Estimated OOMW volumes generated from olive oil processing (Niaounakis and Halvadakis, 2006).

\begin{tabular}{|l|c|c|}
\hline Country & OOMW, $\mathrm{m}^{3} / y$ & Olive cake, $\mathrm{m}^{3} / y$ \\
\hline Spain & $2.8 \times 10^{6}$ & $1.6 \times 10^{6}$ \\
\hline Italy & $2.4 \times 10^{6}$ & $1.6 \times 10^{6}$ \\
\hline Greece & $1.4 \times 10^{6}$ & $0.8 \times 10^{6}$ \\
\hline Tunisia & $0.55 \times 10^{6}$ & $0.3 \times 10^{6}$ \\
\hline
\end{tabular}

Optimization of manufacturing conditions for the production of activated lignites is discussed by Karacan et al., (2006) while its commercialization for various environmental purposes have been undertaken by a large number of industries.

In the present study an effort was undertaken to clean olive oil mill wastewaters (OOMW), which are slightly acidic and associated with high biochemical oxygen demand (BOD) and chemical oxygen demand (COD). The phytotoxic effect of OOMW is partially attributed to organic fraction (phenolics and related substances) which is present in notable concentrations and inhibits the growth of certain microorganisms (Paredes et.al., 1986). The phenolic content (phenols, flavonoids or polyphenols) along with long chain fatty acids produce methanogenic toxicity and therefore the option of discharging OOMW to land should be carefully considered (Hamdi, 1992; D' Annibale et al., 2004; Mekki et al., 2007) the adsorption of phenols. This problem is very serious in the Mediterranean area which accounts for almost $95 \%$ of the world oil production (Al Malah et al., 2000). The estimated OOMW volumes generated from olive oil processing is presented in Table 1.

In the present research work 28 composite lignite samples from 12 coal basins in Greece have been activated in order to measure their surface area. Experiments were conducted on 14 selected raw and activated lignite samples plus one commercially activated lignite sample which was used as a reference point. The aim of the research study was to relate the adsorption of phenols and COD from olive oil mill wastewater, since Greece produces a large amount of OOMW, Table 1, and furthermore to investigate the adsorption of nitrogen and phosphorus from a simulated city waste water by activated Greek lignite samples.

\section{Materials and Methods}

Twenty-eight composite samples of peat, peaty lignites and lignites, of both matrix and xylite-rich lithotypes according to ICCP (1993, Figure 1 and Table 2), have been analyzed using a wide variety of coal characterization methods.

For proximate, ultimate and calorific values, the samples were ground to <100 mesh $(150 \mu \mathrm{m})$ and analyzed following the procedures outlined by ASTM (1978, 1989a, 1989b). Sulphur was determined by LECO apparatus as outlined by Foscolos and Barefoot (1970).

For petrographic composition, the coals were crushed to a maximum particle size of $850 \mu \mathrm{m}$ (20 mesh), mounted in epoxy resin and then ground and polished. Maceral analysis based on 500 points was performed using a LEICA DMRX microscope coupled to a Swift automatic point counter attached to a mechanical stage. The terminology and descriptions for macerals used in this paper is that recommended by the International Committee for Coal Petrology (ICCP, 1963; 1971; 1993, 2001; Sýkorova et al., 2004). 


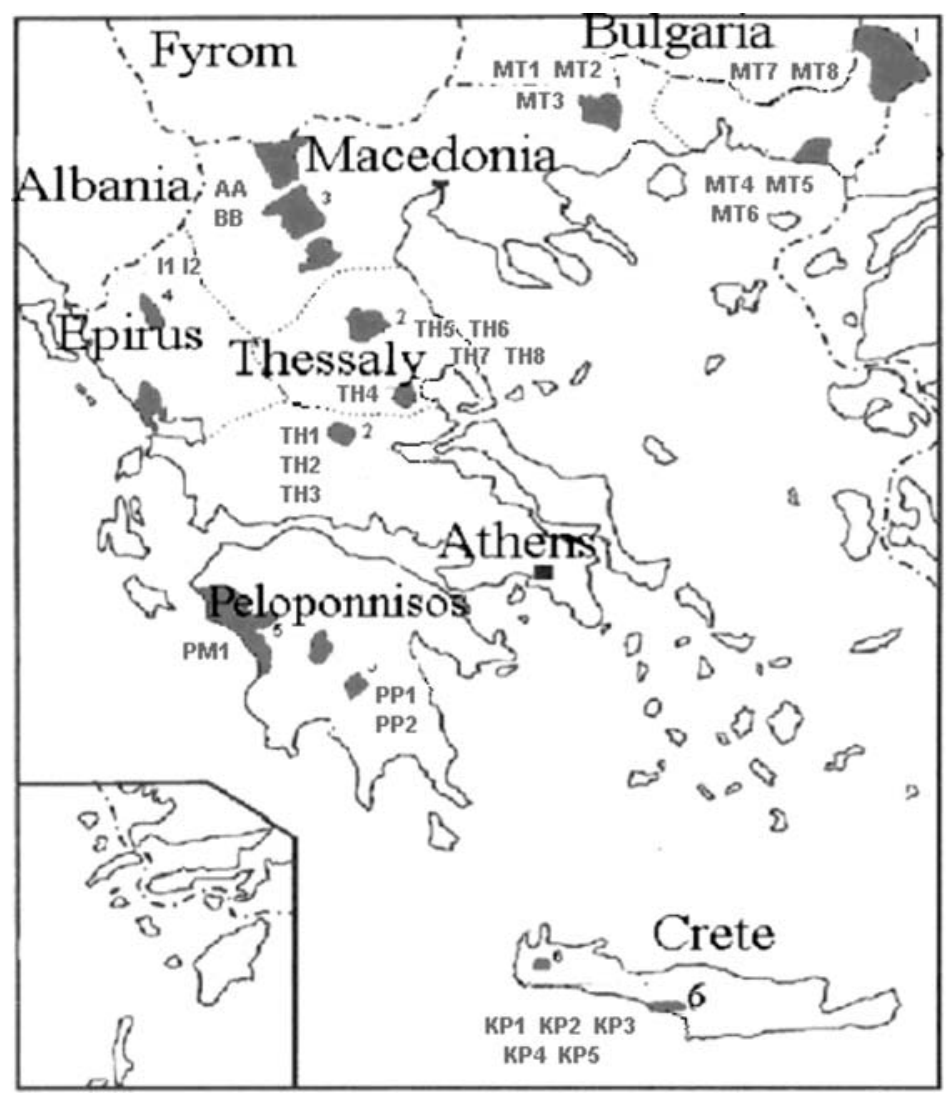

Fig. 1: Location of studied samples.

Adsorption studies were carried out on 28 composite samples from various coal basins. All samples were crushed to an appropriate size particle $(-2.0,+1.00 \mathrm{~mm})$ and then physically activated by pyrolysis. Subsequently, a given quantity of lignite is dried at $110^{\circ} \mathrm{C}$ and placed into the reactor under nitrogen flow $(150 \mathrm{ml} / \mathrm{min})$ for $30 \mathrm{~min}$, in order to remove the air. Afterwards, the samples were pyrolized in two steps at $400^{\circ} \mathrm{C}$ for 2 hours and $700^{\circ} \mathrm{C}$ for another 2 hours under $\mathrm{N}_{2}$ and $\mathrm{CO}_{2}$ gases respectively, following procedure outlined in Zhang et al. 2005. Surface area measurements of non-activated and activated lignites were calculated using the BET (Brunauer, Emmet and Teller) method with $\mathrm{N}_{2}$ as absorbent gas and a NOVA (Quantachrome) surface analyzer. All samples were degassed under vacuum for 12 hours at $300^{\circ} \mathrm{C}$ in order to determine their BET specific surface area $\left(\mathrm{S}_{\mathrm{BET}}\right)$.

For the study of the adsorption of olive mill wastewater 14 raw and activated lignites were used along with commercially activated lignite (AC) in $24 \mathrm{~h}$-adsorption experiments to test their sorption capacity. Experiments were performed at room temperature using a model glass fixed column in a continuous recycling operation. Adsorptive materials were washed out with $2 \mathrm{~L}$ distilled water before the experiment process. Olive oil wastewater was placed into a 10L tank. It was provided at the bottom of the column by a Percom N-M peristaltic pump (fixed at $20 \mathrm{rpm}$ ) and recycled into the tank with a flow rate of $0.5 \mathrm{ml} / \mathrm{s}$. For the phenol measurements $15 \mathrm{ml}$ of wastewater samples were taken at $0,0.5,1,2,4,8$, and $24 \mathrm{~h}$ intervals, while COD was measured at $0,4,12$ and $24 \mathrm{~h}$. The sorption capacity (q) was defined as: $\mathrm{q}=\left(\mathrm{C}_{\mathrm{w}}^{\mathrm{o}}-\mathrm{C}^{1}{ }_{\mathrm{w}}\right) / \mathrm{C}_{\mathrm{a}}^{\mathrm{o}}$, whereas $\mathrm{C}_{\mathrm{w}}^{\mathrm{o}}, \mathrm{C}^{1}{ }_{\mathrm{w}}$ are the concentrations of the ad- 
Table 2. Location of samples and lithotypes.

\begin{tabular}{|c|c|c|}
\hline $\begin{array}{l}\text { Code } \\
\text { Name }\end{array}$ & Origin & Lithotypes \\
\hline TH1 & Thessaly & Peat with clay particles \\
\hline TH2 & Thessaly & Peat with clay particles \\
\hline TH3 & Thessaly & Matrix brown coal, clay - rich, friable \\
\hline TH4 & Thessaly & Matrix brown coal, with plant remnants \\
\hline TH5 & Thessaly & Matrix brown coal, with plant remnants \\
\hline TH6 & Thessaly & Xylite brown coal \\
\hline TH7 & Thessaly & Xylite brown coal \\
\hline TH8 & Thessaly & Matrix brown coal, xylitic, with plant remains \\
\hline MT1 & Macedonia & Mixed peat, clay - rich, black colour \\
\hline MT2 & Macedonia & Mixed peat, clay - rich, black colour \\
\hline MT3 & Macedonia & Mixed peat, clay - rich, black colour \\
\hline MT4 & Thrace & Matrix brown coal, stratified, clay - rich, friable \\
\hline MT5 & Thrace & $\begin{array}{l}\text { Matrix brown coal, stratified, clay - rich, cluster bands containing xylitic } \\
\text { fragments }\end{array}$ \\
\hline MT6 & Thrace & $\begin{array}{l}\text { Matrix brown coal, stratified, clay - rich, cluster bands containing xylitic } \\
\text { fragments }\end{array}$ \\
\hline MT7 & Thrace & $\begin{array}{l}\text { Matrix brown coal, stratified, clay - rich, cluster bands containing xylitic } \\
\text { fragments }\end{array}$ \\
\hline MT8 & Thrace & Matrix brown coal, stratified, cohesive at places, presence of micas \\
\hline PP1 & Peloponnese & Matrix brown coal, stratified, xylitic at places \\
\hline PP2 & Peloponnese & Matrix brown coal, xylitic \\
\hline PM1 & Peloponnese & Matrix brown coal, stratified, clay-rich \\
\hline I1 & Epirus & Matrix brown coal \\
\hline $\mathbf{I} 2$ & Epirus & Matrix brown coal, clay rich \\
\hline KP1 & Crete & Subbituminous, lustreous appearance \\
\hline KP2 & Crete & Subbituminous, mat / lustreous appearance \\
\hline KP3 & Crete & Brown matrix coal, layered at places, mat / glossy \\
\hline KP4 & Crete & Organic matter bearing clay, layered, cohesive in some places \\
\hline KP5 & Crete & Mixture of KP1 and KP2 at a ratio 1:2 \\
\hline
\end{tabular}

sorbate in the wastewater $(\mathrm{mg} / \mathrm{L})$ at zero and interval time, while $\mathrm{C}^{\circ}{ }_{\mathrm{a}}$, is the mass per volume ratio of adsorbent versus wastewater $(\mathrm{g} / \mathrm{L})$. Total phenol content was determined colorimetrically using the Folin-Ciocalteau reagent (Atanassova et al., 2005; Folin and Ciocalteau, 1927).

The adsorption of $\mathrm{N}$ and $\mathrm{P}$ from a city wastewater disposal was carried out using the following simulated liquid, Aivazidis, 2000. 20g. of peptone along with $20 \mathrm{~g}$ of sugar, $4.76 \mathrm{ml}$ of glacial acetic acid, $5.62 \mathrm{~g}$ of $\mathrm{KH}_{2} \mathrm{PO}_{4}$ and $6.48 \mathrm{~g}$ of urea $\left(\mathrm{NH}_{2}\right)_{2} \mathrm{CO}_{3}$ were transferred to one liter of distilled water. 
$30 \mathrm{ml}$ of this solution were transferred to 3 liters of distilled water. This final solution was used for measuring COD decrease as well as $\mathrm{N}$ and $\mathrm{P}$ adsorption by activated lignite samples. Nitrogen and phosphorus measurements were carried out usinga Hanna C214 Multiparameter Bench Photometer for Wastewater Treatment Application along with the special reagents. For the adsorption of N and $\mathrm{P}$ measurements were carried out at $0.5,3,6$ and 12 hours intervals while for COD measurements the intervals were 3,6 , and 12 hours respectively.

\section{Results and Discussion}

\subsection{Proximate and UltimateAnalysis and Calorific Values}

Table 3 shows the data obtained from the proximate and ultimate analysis together with the calorific values. Proximate analysis indicates that the samples of peat and peaty lignites: I1 and I2 (Epirus), PM1, PP1 and PP2 (Peloponnesus), TH1, TH2 and TH3 (Thessaly), as well as the samples MT1, MT2 and MT3 (Macedonia, N. Greece) to have high volatile content ranging from 66 to $76.8 \%$, while its fixed carbon content to vary from 23.2 to $35.6 \%$. High values are recorded for oxygen and nitrogen, which fluctuate from 25.6 to $34.6 \%$ and from 2.1 to $3.7 \%$, respectively. These results are indicative of their low maturity. Also the samples I1 and I2 are characterized from their high sulfur content, 6.6 to $6.5 \%$, which attributed to the presence of pyrite (Papanicolaou, 2001).

For the samples with higher maturity TH4, TH5, TH6, TH7, TH8 (Thessaly), MT4, MT5, MT6, MT7, MT8 (Thrace), as well as for the xylite rich samples AA and BB (Macedonia, N. Greece) their volatile matter content ranges from 49.8 to $61.9 \%$, while their fixed carbon content fluctuates between 38.1 to $50.2 \%$. Oxygen content ranges from 23.4 to $30.3 \%$, while nitrogen concentration varies from 0.5 to $1.7 \%$, which indicates different maturation. The latter is also ascertained from the higher calorific values (Table 2). Noteworthy is the presence of high sulfur content, 14.9 to $18.8 \%$ on the samples MT4, MT5 and MT6 (Macedonia) and 5.5 and $7.1 \%$ from the samples MT7 and MT8 (Thrace). These values are attributed to the presence of pyrite, which is also indicative of their depositional environment (Papanicolaou, 2001).

Sub-bituminous coals, KP1, KP2, KP3 and KP5 (Crete), are also characterized by their high sulfur values, which range from 6.9 to $19 \%$ due to the presence of pyrite, as well as their high calorific values, up to $26.5 \mathrm{MJ} / \mathrm{kg}$. Sample KP4 is a carbonaceous clay sample intercalating the coal seams.

Finally, the samples PM1, PP1 and PP2 (Peloponnesus), are characterized by high volatile content, $>62 \%$, relatively high sulfur content $>5.5 \%$ and relatively low calorific values that range from 20.6 $\mathrm{MJ} / \mathrm{kg}$ to $20.8 \mathrm{MJ} / \mathrm{kg}$.

\subsection{Maceral Composition}

Maceral composition of the studied samples is presented in Table 4. In general huminite is the predominant maceral group, whereas liptinite and inertinite occur with very low values. Peat and peaty lignite samples differ in more than one maceral sub-group. Peat from Thessaly (TH1, TH2, TH3), have low concentrations of telohuminite ranging from 15.3 to $17.6 \mathrm{vol} . \%$, while their detrohuminite fluctuates from 69.2 to $72 \mathrm{vol} . \%$ (Fig. 2). Noteworthy is the fact that within the detrohuminitic components the ratio of attrinite to densinite is quite high On the other hand peat and peaty lignite samples from Macedonia (MT1, MT, MT3), though they have similar telohuminitic concentrations, as the previously mentioned samples from Thessaly, their ratio of attrinite to densinite is much lower. Peaty lignite samples from Epirus (I1, I2), are characterized by higher telohuminitic content than the peat and peaty lignite samples from Thessaly and Macedonia. Moreover, these samples have less de- 
Table 3. Results of proximate and ultimate analysis and calorific values of lignite samples (except ash values are on dry and free ash basis).

\begin{tabular}{|l|c|c|c|c|c|c|c|c|c|}
\hline Location & Ash & Vol. Mat. & C $_{\text {Fixed }}$ & C & H & O & N & S & Cal. Val. \\
\hline \multicolumn{7}{|c|}{ wt. } \\
\hline Thessaly \\
\hline TH-1 & 47.6 & 66.0 & 34.0 & 55.7 & 5.6 & 33.8 & 2.7 & 2.2 & 21.6 \\
\hline TH-2 & 58.8 & 66.3 & 33.7 & 55.1 & 5.7 & 34.6 & 2.7 & 1.8 & 18.82 \\
\hline TH-3 & 37.4 & 66.9 & 33.1 & 59.7 & 5.0 & 30.5 & 3.1 & 1.6 & 22.7 \\
\hline TH-4 & 24.4 & 55.4 & 44.6 & 65.4 & 4.7 & 24.0 & 1.4 & 4.5 & 25.1 \\
\hline TH-5 & 39.6 & 61.2 & 38.8 & 63.5 & 5.5 & 28.0 & 1.7 & 1.3 & 24.5 \\
\hline TH-6 & 45.4 & 58.8 & 41.2 & 60.8 & 5.6 & 30.3 & 1.5 & 1.8 & 23.6 \\
\hline TH-7 & 17.3 & 56.9 & 43.1 & 65.8 & 5.0 & 25.1 & 1.5 & 2.6 & 25.5 \\
\hline TH-8 & 38.1 & 57.3 & 42.7 & 64.4 & 5.7 & 25.0 & 1.4 & 3.0 & 25.4 \\
\hline
\end{tabular}

Greek Macedonia \& Thrace

\begin{tabular}{|c|c|c|c|c|c|c|c|c|c|}
\hline AA & 8.7 & 59.2 & 40.9 & 67.9 & 5.9 & 23,4 & 0,5 & 2,2 & 27.6 \\
\hline BB & 13.2 & 57.6 & 42.4 & 64.6 & 4,1 & 26,2 & 1,1 & 3,9 & 23.6 \\
\hline MT-1 & 52.5 & 64.4 & 35.6 & 58.3 & 5.5 & 29.0 & 2.1 & 5.1 & 21.8 \\
\hline MT-2 & 41.5 & 67.9 & 32.1 & 61.6 & 5.4 & 25.7 & 2.3 & 5.1 & 23.6 \\
\hline MT-3 & 40.2 & 67.5 & 32.5 & 62.4 & 4.8 & 27.6 & 2.5 & 3.1 & 23.2 \\
\hline MT-4 & 52.8 & 53.2 & 46.5 & 52.6 & 5.2 & 26.4 & 0.9 & 14.9 & 20.1 \\
\hline MT-5 & 43.0 & 49.8 & 50.2 & 51.3 & 4.8 & 24.4 & 0.8 & 18.8 & 19.4 \\
\hline MT-6 & 48.0 & 52.3 & 47.7 & 53.6 & 5.0 & 25.6 & 1.0 & 14.9 & 20.3 \\
\hline MT-7 & 51.0 & 54.5 & 45.5 & 62.0 & 5.8 & 25.7 & 1.1 & 5.5 & 24.1 \\
\hline MT-8 & 64.6 & 61.9 & 38.1 & 56.5 & 6.4 & 29.3 & 0.7 & 7.1 & 17.6 \\
\hline Crete & & & & & & \\
\hline
\end{tabular}

Crete

\begin{tabular}{|c|c|c|c|c|c|c|c|c|c|}
\hline KP-1 & 30.2 & 51.5 & 48.5 & 66.6 & 4.9 & 20.4 & 1.0 & 7.1 & 26.5 \\
\hline KP-2 & 52.8 & 54.2 & 45.8 & 60.3 & 4.8 & 22.1 & 0.9 & 11.9 & 23.7 \\
\hline KP-3 & 72.0 & 61.7 & 38.3 & 52.1 & 4.6 & 26.3 & 1.2 & 15.8 & 17.5 \\
\hline KP-4 & 83.2 & 81.1 & 18.9 & 41.6 & 5.4 & 32.7 & 1.2 & 19.0 & 11.7 \\
\hline KP-5 & 30.1 & 52.3 & 47.7 & 66.6 & 5.0 & 20.9 & 0.9 & 6.9 & 26.6 \\
\hline Epirus & \multicolumn{7}{|l|}{} \\
\hline I-1 & 48.5 & 74.9 & 25.1 & 58,5 & 3.5 & 29.3 & 3,5 & 6,6 & 19.9 \\
\hline I-2 & 51.5 & 76.8 & 23.2 & 57.5 & 3.7 & 30.1 & 3,7 & 6,5 & 19.7 \\
\hline Pel
\end{tabular}

\section{Peloponnese}

\begin{tabular}{|c|c|c|c|c|c|c|c|c|c|}
\hline PM-1 & 39.5 & 66.4 & 33.6 & 58.1 & 4.0 & 30.8 & 1,6 & 5,6 & 20.6 \\
\hline PP-1 & 43.4 & 64.7 & 35.3 & 57.2 & 4.3 & 31.0 & 1,5 & 6,0 & 20.8 \\
\hline PP-2 & 36.1 & 62.0 & 38.0 & 59.6 & 4.2 & 28.6 & 1,5 & 6,1 & 20.8 \\
\hline
\end{tabular}




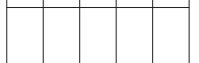

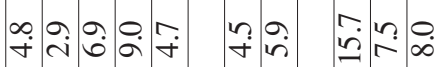

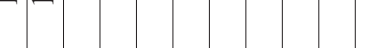

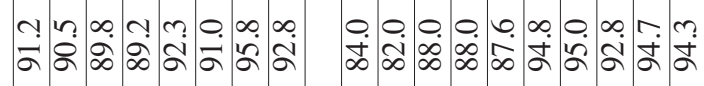

c) - - 0 m

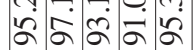

0

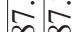

a. 0.0

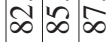

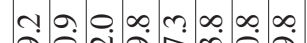

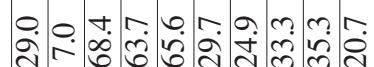

$\infty$ n. + a.

ণ

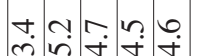

ปูi

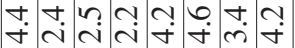

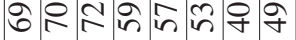

กิ

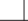

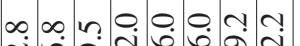

i

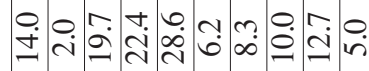

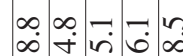

의

$\because \bar{\sim}$

$0 . \infty$

$\nabla n$

ก ก ก nิ 8 in

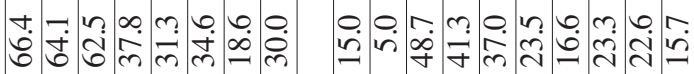

$0 . m \infty$

ป \pm i̊ñ

กุ.

ก ก

\section{-}

(

I

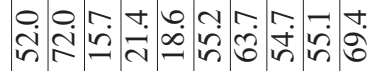

ㅇ.

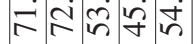

$\underset{\forall}{\forall}$

\begin{tabular}{ll|l}
0 & 0 \\
0 & 0 & 0 \\
0 & 0 & 0 \\
0 & 0 & 0
\end{tabular}

$\infty .0$ m t $\infty$ n t

ป்

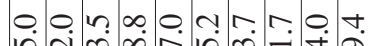

ช่

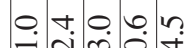

त.

(․)

भंष्त

$\begin{array}{lll}0 & 0 & 0 \\ 0 & 0 & 0 \\ 0 & 0 & 0\end{array}$

:

:0․ㅠ.:

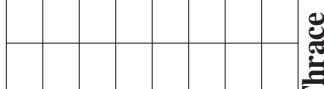

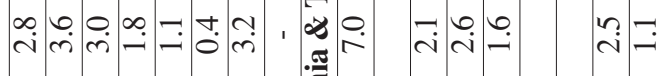

苞

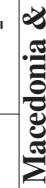

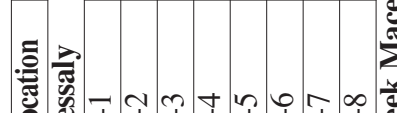
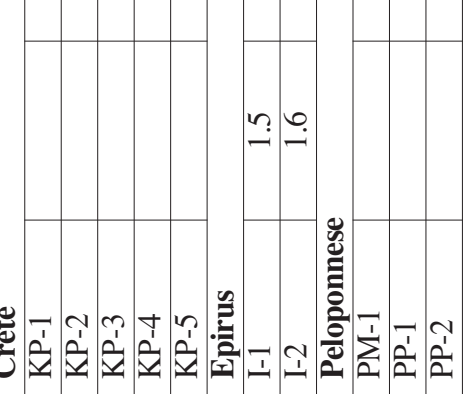


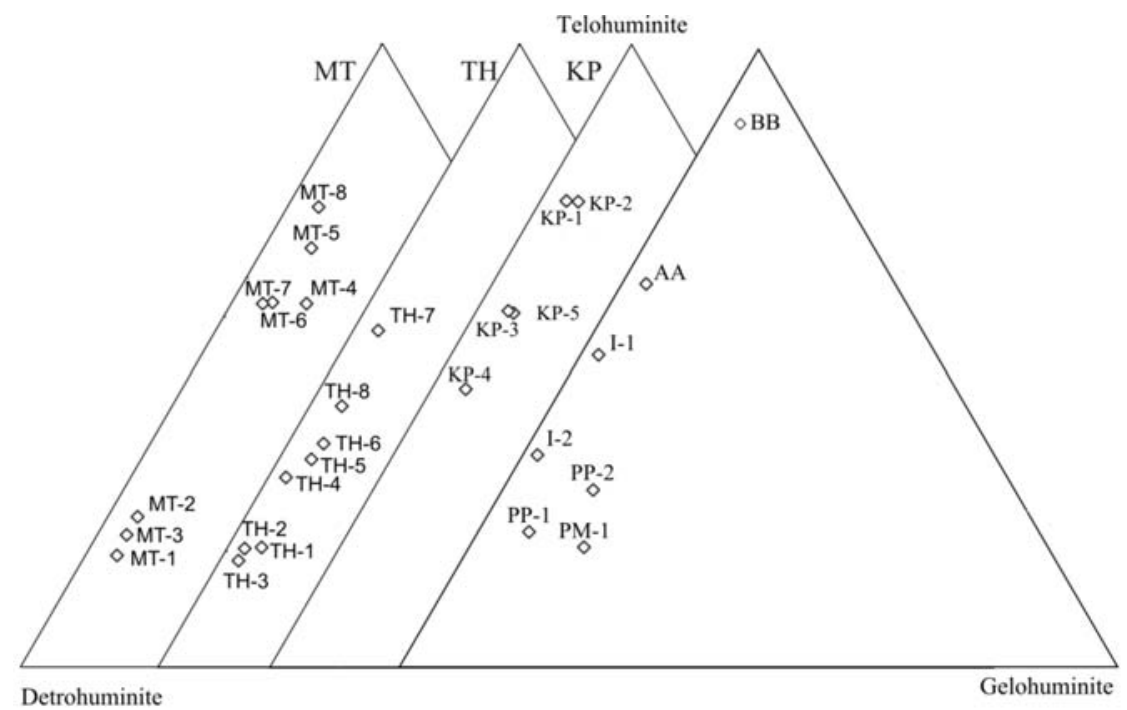

Fig. 2: Ternary plot of huminite maceral subgroup contents.

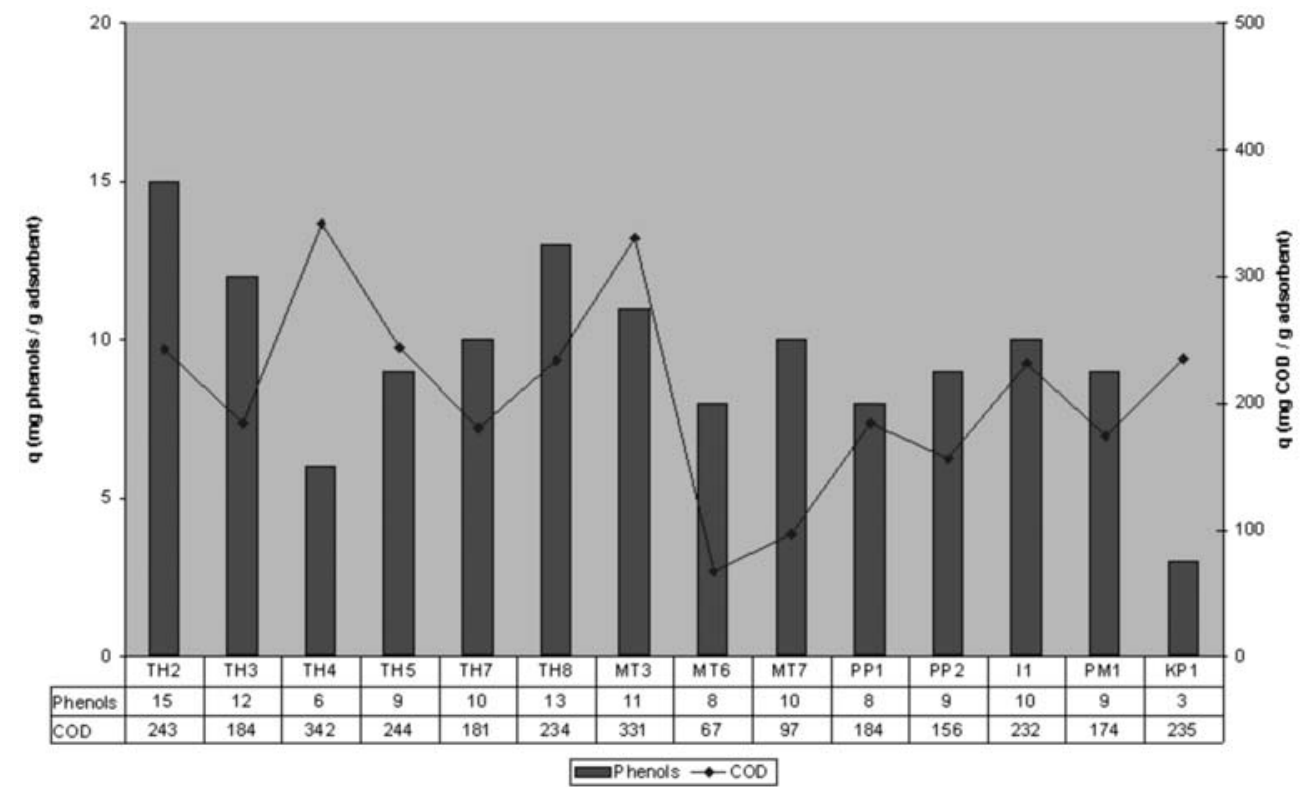

Fig. 3: Sorption capacity q (mg adsorbate / $\mathrm{g}$ adsorbent) of phenols and COD for the 14 raw lignite samples at the end of the $24 \mathrm{~h}$ experiments.

trohuminitic and gelohuminitic content while their inertinitic concentration is higher than their equivalent samples from Thessaly and Macedonia.

Lignite samples from Thessaly TH4, TH5, TH6 and TH8 are characterized by relatively high telohuminitic content ranging from 30.8 to 38.6 vol.\%, while detrohuminitic components are higher fluctuating from 49.8 to 59.8 vol. $\%$. 
Table 5. Surface area (BET) in $\mathrm{m}^{2} / \mathrm{g}$ of bulk and activated lignites.

\begin{tabular}{|c|c|c|c|c|c|}
\hline Location & Bulk sample & Activated sample & Location & Bulk sample & Activated sample \\
\hline \multicolumn{3}{|l|}{ Thessaly } & \multicolumn{3}{|l|}{ Crete } \\
\hline TH1 & 3.1 & 158.5 & KP1 & 3.1 & 241.2 \\
\hline TH2 & 14.0 & 112.1 & KP2 & 5.2 & 144.3 \\
\hline TH3 & 3.1 & 226.5 & KP3 & 8.6 & 82.5 \\
\hline TH4 & 4.3 & 247.4 & KP4 & 10.8 & 50.1 \\
\hline TH5 & 7.6 & 189.7 & KP5 & 5.7 & 125.1 \\
\hline TH6 & 11.5 & 145.6 & \multicolumn{3}{|l|}{ Epirus } \\
\hline TH7 & 3.6 & 271.3 & I1 & 3.6 & 186.4 \\
\hline TH8 & 5.0 & 202.2 & I2 & 4.3 & 164.1 \\
\hline \multicolumn{3}{|c|}{ Eastern Greek Macedonia \& Thrace } & \multicolumn{3}{|c|}{ Western Greek Macedonia } \\
\hline MT1 & 3.0 & 140.9 & $\mathbf{A A}$ & & 299.2 \\
\hline MT2 & 4.2 & 168.2 & BB & & 412.4 \\
\hline MT3 & 3.7 & 233.9 & \multicolumn{3}{|c|}{ Western Peloponnese } \\
\hline MT4 & 6.8 & 155.1 & PM1 & 8.7 & 227.6 \\
\hline MT5 & 16.8 & 161.3 & PP1 & 5.1 & 207.6 \\
\hline MT6 & 6.9 & 194.1 & PP2 & 3.4 & 184.8 \\
\hline MT7 & 8.7 & 118.3 & & & \\
\hline MT8 & 23.8 & 88.6 & & & \\
\hline
\end{tabular}

Lignite samples from western Peloponnesus PM1, PP1, and PP2 have much lower telohuminitic components than the ones from Thessaly ranging from 16 to 25 vol.- $\%$, while their detrohuminitic components are relatively similar varying from 51.0 to 60.2 vol.- $\%$. Moreover, the samples from western Peloponnese are also characterized from higher liptinite and inertinite macerals. Samples TH7 and TH8 from Thessaly and MT4, MT5, MT6, MT7 and MT8 from Thrace, as well as all the samples from Crete have high telohuminitic components mainly as eu-ulminite. The difference amongst these samples lies upon the range of detrohuminite concentration. The concentration in samples from Thessaly, TH7 and TH8 varies from 40.8 to 49.8 vol. \%, while those from Thrace MT7 and MT8, fluctuate from 20.7 to 35.3 vol.\% and those from Crete have wider ranges, which varies from 19.5 to 45.9 vol.\% (Table 3 ).

Finally, the two samples AA and BB, from western Macedonia are characterized by their high telohuminitic components and liptinite macerals and their low detrohuminitic components and the absence of inetrinite macerals.

\subsection{Surface area measurements}

Surface area measurements on non-activated and activated lignite have been measured following the BET method. The results are presented in Table 5 and indicate that in all samples the activation process has increased their surface area substantially, e.g. KP1 from Crete, TH3, TH4 and TH7 from Thessaly. 


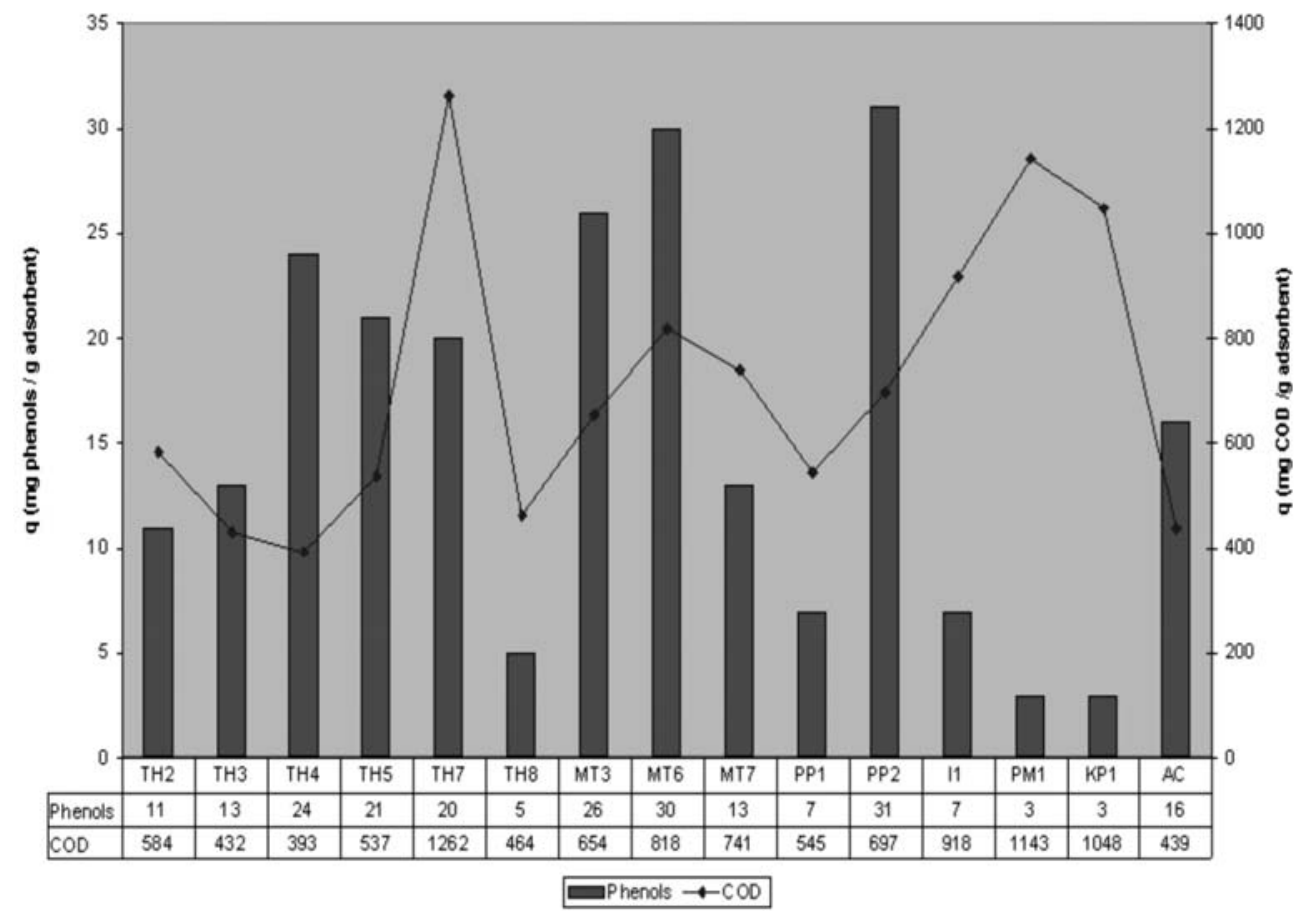

Fig. 4: Sorption capacity q (mg adsorbate / $g$ adsorbent) of phenols and COD for the 15 activated lignite samples at the end of the $24 \mathrm{~h}$ experiments.

\subsection{Adsorption studies}

The adsorption capacity q ( $\mathrm{mg}$ adsorbate/g adsorbent) of phenols from the olive mill waste water was estimated according to the reduction of total phenols and COD at the end of 24 hours experiment for 14 raw and activated lignite samples as well as for one commercially available one (AC).

From the raw lignites, samples TH2, TH8, TH3, I1 and MT3 have q values over $10 \mathrm{mg}$ of phenol /g lignite which are relatively good while the $\mathrm{q}$ value of the commercially available activated lignite (AC) is $15 \mathrm{mg}$ of phenol/ $\mathrm{g}$ lignite (Figure 4). As far as the COD reduction only two samples MT6 and MT7 have values, $67 \mathrm{mg} \mathrm{COD} / \mathrm{g}$ lignite and $97 \mathrm{mg} / \mathrm{g}$ lignite which are lower than the AC sample $439 \mathrm{mg} \mathrm{COD} / \mathrm{g}$ lignite. From the activated lignite, samples PP 2, MT6, MT3 and TH4 have q values of over $26 \mathrm{mg} / \mathrm{g}$ act. lignite while the commercial AC yield a value of $16 \mathrm{mg} / \mathrm{g}$ act. lignite (Figure 5). As far as COD values are concerned, samples TH7, PPI and KP1 have better values, $1262 \mathrm{mg} / \mathrm{g}$ act. lignite, $1143 \mathrm{mg} / \mathrm{g}$ act. lignite and $1048 \mathrm{mg} / \mathrm{g}$ act. lignite respectively, than AC sample which has $271 \mathrm{mg} / \mathrm{g}$ act. lignite.

Data concerning the decrease of COD, nitrogen and phosphorus from the simulated city wastewater disposal following the adsorption from raw and activated lignite samples are shown in Figures 5, 6 and 7 , respectively.

The decrease of COD demand in raw lignite samples at a half hour interval, Fig.5, indicates that samples KP1, MT6, MT8, I1 and TH4 with q values $7.5 \mathrm{mg} / \mathrm{g}, 7.3 \mathrm{mg} / \mathrm{g}, 7.2 \mathrm{mg} / \mathrm{g}, 7.0 \mathrm{mg} / \mathrm{g}$ and 6.7 $\mathrm{mg} / \mathrm{g}$, respectively yield higher values than the commercially activated sample, $\mathrm{AC}$, whose value was 


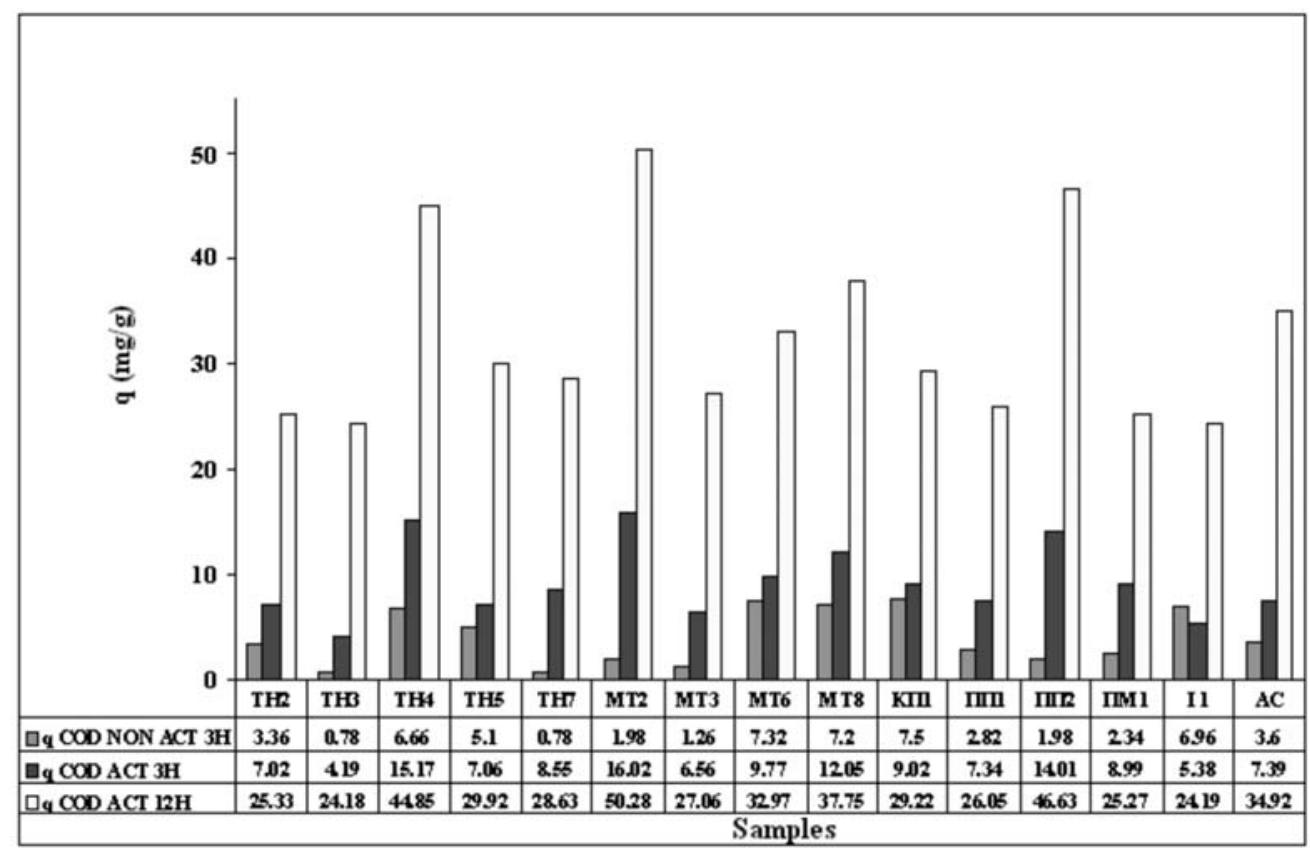

Fig. 5: Decrease in COD demand in $\mathrm{mg} / \mathrm{g}$ from a simulated wastewater liquid in both raw lignite samples after half an hour interval and activated lignite samples after 3 hours and 12 hours interval.

$3.6 \mathrm{mg} / \mathrm{g}$. The decrease, in q value, of COD in activated lignite samples at the time interval of 3 hours, Fig. 5, was in the following order:

MT2 > TH4 > PP2> MT8> MT6> KP1 >PM1 > TH7>AC

while at 12 hour interval the order was:

\section{MT2>PP2 $>$ TH4 $>$ MT8 $>$ AC $>$ MT6 $>$ TH5 $>$ TH5 $>$ KP1 $>$ MT3}

The decrease in q value for nitrogen adsorption at the end of 12 hours, Fig. 6, was in the following order:

$$
\mathrm{MT} 2>\mathrm{I} 1>\mathrm{PM} 1>\mathrm{TH} 4=\mathrm{PP} 1>\mathrm{PP} 2>\mathrm{TH} 7>\mathrm{MT} 8>\mathrm{MT} 6>\mathrm{AC}
$$

The decrease in q value for phosphorus adsorption at the end of 12 hours, Fig. 7, was in the following order:

\section{$\mathrm{I} 1>\mathrm{AC}>\mathrm{TH} 4>\mathrm{PP} 2>\mathrm{MT} 8>\mathrm{PM} 1>\mathrm{TH} 5$}

From the above experimental data it is more than obvious that a large number of Greek activated lignite samples can be used successfully to clean industrial and city wastewaters since they behave better than the commercially available one $\mathrm{AC}(\mathrm{HOK})$ produced by Rheinbraun Brennstoff Gmbh (RBB).

Table 1 shows that every year $1.4 \times 10^{6} \mathrm{~m}^{3}$ of OOMW is produced in Greece. Since $\mathrm{I} \mathrm{m}^{3}$ of OOMW contains $1.8 \mathrm{~g} / \mathrm{l}$ of phenols it is calculated that the amount of phenols contained in the $1.4 \times 10^{6} \mathrm{~m}^{3}$ amounts to 2520 tons. Given that sample PP1 adsorbs $30 \mathrm{mg}$ of phenols $/ \mathrm{g}$ of activated lignite then to clean the annual effluent of OOMW requires 84000 tons of this type of lignite per year. Assuming that we have a small mineable lignite deposit of 5000000 tons then upon activation the amount left is 


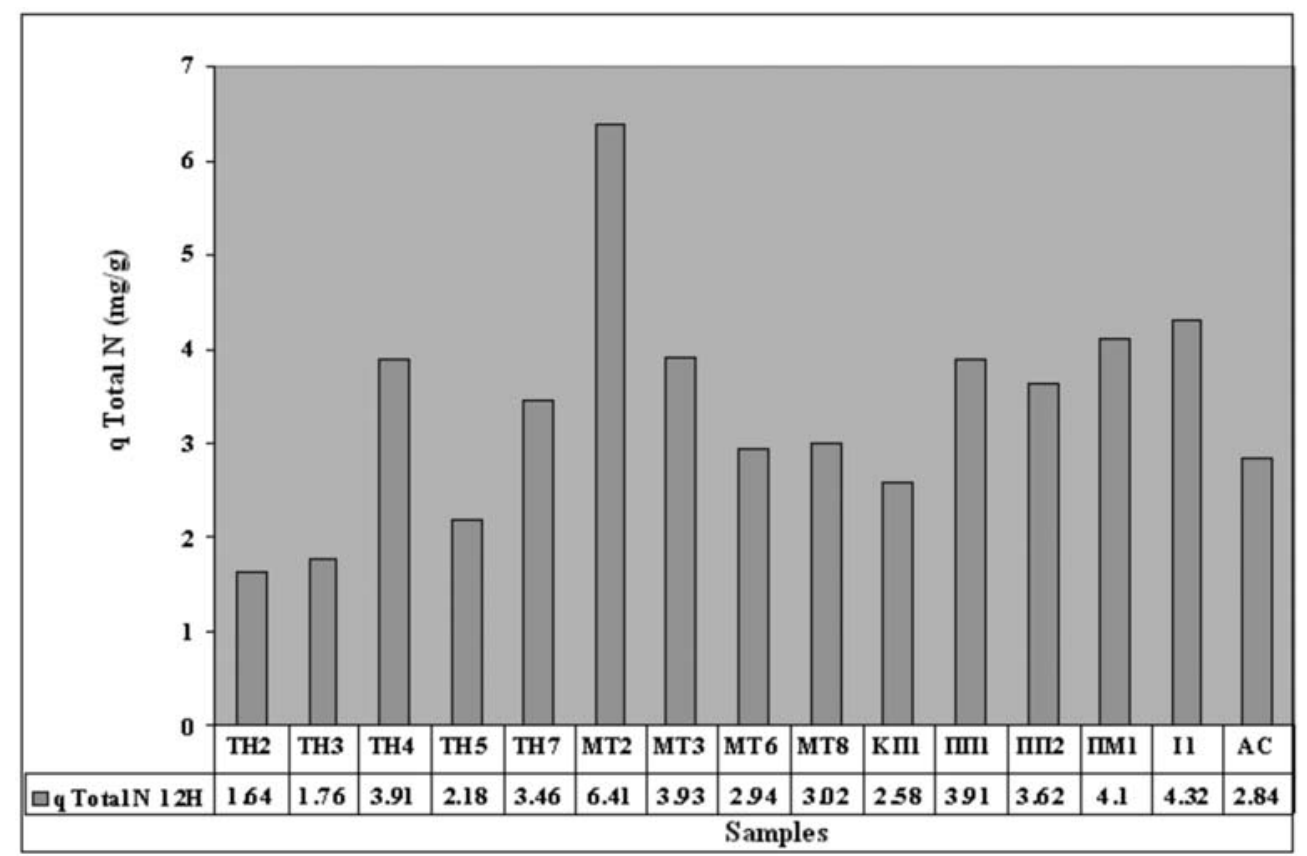

Fig. 6: Nitrogen adsorption in $\mathrm{mg} / \mathrm{g}$ on activated lignite samples from a simulated wastewater liquid after 12 hours contact.

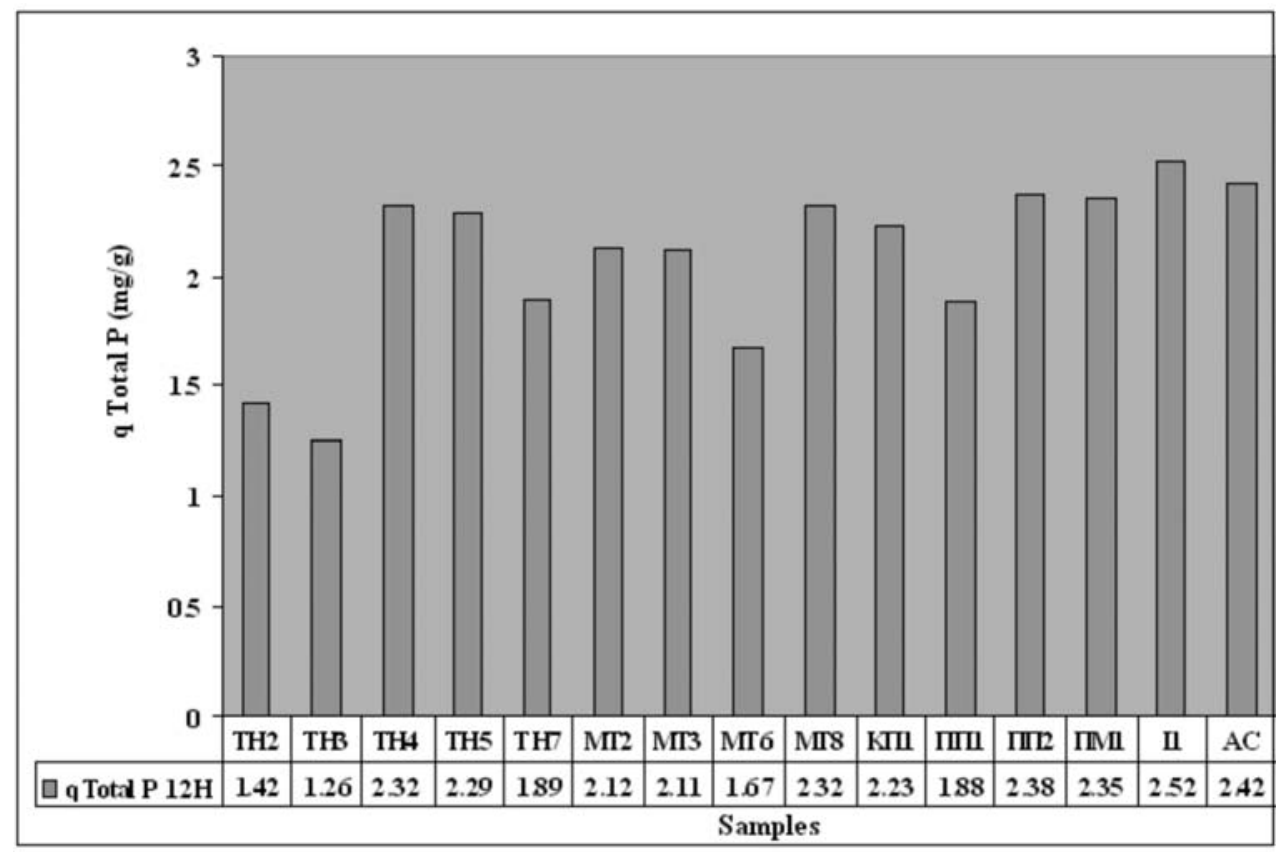

Fig. 7: Phosphorus adsorption, in $\mathrm{mg} / \mathrm{g}$ on activated lignite samples from a simulated wastewater liquid after 12 hours contact. 


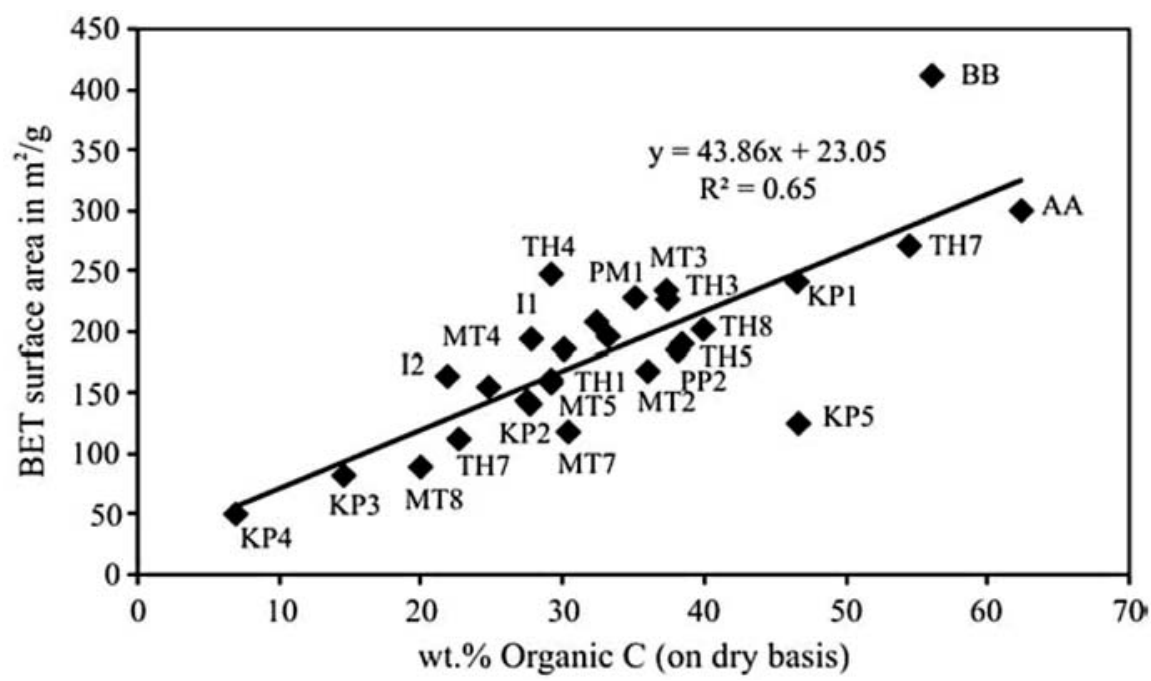

Fig. 8: Relationship between surface area of physically activated lignite samples $\left(\mathrm{m}^{2} / \mathrm{g}\right)$ and their carbon content on dry samples.

roughly 2500000 tons since more than $50 \%$ of its weight is lost during the activation process. This implies that such a deposit can satisfy the cleaning process of OOMW in Greece for 30 years.

The 84000 tons of contaminated by phenols activated lignite can be used for the production of valuable by-products (Roig et. al., 2006: Oreopoulou and Russ, 2007). Activated lignite which is saturated with phenols can not be applied in soils as fertilizers because it inhibits the growth of certain bacteria (Paredes et al., 1986).

\section{Conclusions}

Surface area measurements have been conducted on 28 activated Greek brown coal samples. The results show that some lignite samples such as AA and BB (from northern Macedonia) and TH7 and TH4 from Thessaly, central Greece) have high surface area equal or better than that of the commercial activated carbon sorbents.

Surface area of activated lignite samples is inversely proportional to ash and proportional to carbon content of lignite samples.

The use of activated lignite samples as adsorptive materials for cleaning olive mill wastewater contaminants and consequently for environmental purpose was successful. Maximum recorded adsorption of phenol was recorded on sample PP1 with a value of $30.6 \mathrm{mg} / \mathrm{g}$ of activated lignite while the commercial one (AC) adsorbed $14 \mathrm{mg} / \mathrm{g}$ of activated lignite. The maximum COD reduction was recorded on sample TH7 with a value of $1262 \mathrm{mg} / \mathrm{g}$ of activated lignite while in the commercial one the reduction was $439 \mathrm{mg} / \mathrm{g}$ of activated lignite.

Based upon the results obtained form the study of a simulated wastewater disposal liquid, a substantial number of Greek activated lignite samples reduce COD as well as nitrogen and phosphorus content more efficiently than the commercially available activated lignite HOK which produced by Rheinbraun Brennstoff Gmbh (RBB). 


\section{Acknowledgments}

This research was funded by EU and the Greek Ministry of Development through the 3rd Community Support Framework, Competitiveness Operational Programme.

\section{References}

Aivazides, A. 2000. Technologia Diachirissis Ygron Apovliton, Panepistimiako Sygramma Dimokritio Panepistimio Thrakis, Xanthi p. 56 ( Translation in Greek of the "Handbuch zur Schott-AnaerobTesteinheit", 1987. Shott Glaswerke Mainz, Geschaftsbereich Chemie, Apparate-u. Anlagebau, Bioprozesstechnik, $56 \mathrm{p}$.

Al-Malah, K., M.O.J. Azzam and N.I. Abu-Lail 2000. Olive mills effluent (OME) Waste water post-treatment using activated clay. Separation and Purification Technology, 20, pp. 225-234.

Allen, S. J., Whitten, L. J., Murray, M., Duggan, O. 1997. The adsorption of pollutants by peat, lignite and activated chars. Jour. of Chemical Technology and Biotechnology, 68, pp. 442-452.

American Society for Testing and Materials (ASTM) 1978.Annual book of ASTM standards. Part 26. Proximate analysis of coal and coke.D3172-3173, ultimate analysis of coal and coke, D 3174-3176. ASTM Philadelphia, PA : 380, 390-391.

American Society for Testing and Materials (ASTM) D3174,1989. Standard method of ash in the analysis sample of coal and coke from coal. 1989 Annual Book of ASTM Standards, Part 26, Gaseous Fuels: Coal and Coke. ASTM, Philadelphia, PA, pp. 291-294.

American Society for Testing and Materials (ASTM) D3302, 1989. Standard method of total moisture in coal. 1989 Annual Book of ASTM Standards, Part 26, Gaseous Fuels:Coal and Coke. ASTM, Philadelphia, PA, pp. 326- 332 .

Atanassova, D., P. Kefalas and E. Psillaki (2005). Measuring the antioxidant activity of olive oil mill wastewater using chemiluminescence. Environ. International, 31,2, pp. 275-280.

Dabrowski, A., Podkoscielny, P., Hubicki,Z., Barczak, M. 2005. Adsorption of phenolic compounds by activated carbon: A Critical Review. Chemosphere, 58, pp. 1049-1070.

D’ Annnibale, A., Casa R., Pieruccetti, F., Ricci, M., Marabotini, R. 2004. Lentula edodes removes phenols from olive mill wastewater ; impact on durum wheat (Triticum durum Desf.) grminability. Chemosphere 54: 887-894.

Engelhard, J., Lenz, U.1997. Lignite coke in water and waste gas clean-up Proceedings of the 11th International Conference on Coal Research, Calgary, Alberta, Canada September 9-12, 1997, pp. 355-368.

Folin, O. and V. Ciocaltaeu (1927) 'On tyrosine and tryptophan determination in protein. J. of Biology and Chemistry, 73, pp. 627-50.

Foscolos, A.E., Barefoot, R.R., 1970. A rapid determination of total organic and Inorganic and inorganic carbon in shales and carbonates-A rapid determination of total sulphur in rocks and minerals. Geol. Surv. Can. pp. 70-11.

Fraser, K. M.1972. Sorptive mode of activated lignite char. Ph. D. Thesis Libr. Univ. of Calgary, 91 p.

Galanakis, C., Dimou, D., Pasadakis, .N., Papanicolaou, C., Gekas, V. 2006. Adsorption of olive mill wastewater on raw and activated Greek lignites. Protection and Restoration of the Environment VIII, Chania 2006: http://www.ath.aegean.gr/srcosmos/generic_pinakas.aspx?pinakas= publications\&author_name=Galanakis $\% 20 \mathrm{C}$

Hamdi, M., Ellouz, R. 1993. Treatment of detoxified olive mill wastewaters by anaerobic filter and aerobic fluidized bed process. Envirn. Technol. 14 (2) : 183-188.

International Committee for Coal Petrology (ICCP), 1963. International Handbook of Coal Petrography, 
$2^{\text {nd }}$ edition. Centre National de la Recherche Scientifique, Paris, France.

International Committee for Coal Petrology (ICCP), 1971. International Handbook of Coal Petrography, $1^{\text {st }}$ supplement to $2^{\text {nd }}$ edition. Centre National de la Recherche Scientifique, Paris, France.

International Committee for Coal Petrology (ICCP), 1993. International Handbook of coal petrography, $3^{\text {rd }}$ supplement to $2^{\text {nd }}$ edition. Centre National de la Recherche Scientifique, Paris, France.

International Committee for Coal and Organic Petrology (ICCP), 2001. The new inertinite classification (ICCP System 1994). Fuel 80, 459-471.

Karacan, F., Ozden, U., Karacan, S. 2006. Optimization of manufacturing conditions for activated carbon from Turkish lignites by chemical activation using response surface methodology. Applied Thermal Engineering, 27 (7) SPEC. ISS., May 2006 pp. 1212-1218.

Khan, K.A., Suidan, M.T., Cross, W.H. 1981. Anaerobic activated carbon filter for the treatment of phenol-bearing wastewater. J. Water Pollut. Control Fed.: Vol/Issue: 53:10, pp. 1519-1532.

Klose, E., Heschel, W. 1987. Zur eignung von braunkohlenkoksen fuer die aktivkohleherstellung. Chemische Technik (Leipzig) 39 (2), pp.70-74.

Mekki, A., Dhouib, A., Sayadi,S., 2007. Polyphenols dynamics and phytotoxicity in a soil amended by olive mill wastewaters. J. Environ. Manag. 84: 134-140.

Niaounakis, M., Halvadakis,C.,P. 2006.Olive Processing Waste Management: Literature Review and Patent Survey, $2^{\text {nd }}$ Edition, Series 5, Elsevier Publication 498 p. ISBN-10 0-08-044851-8.

Navarro, M.V., Murillo, R., Lopez, J.M., Garcia, T., Callen, M.S., Mastral, A.M.2006. Modeling of activated carbon production from lignite. Energy and Fuels, 20 (6) pp. 2627-2631.

Olson, E.S., Stepan, D.J. 2000. Subtask 1.5-Activated carbon from lignite for water treatment. U S. Department of Energy, National Energy Technology Laboratory, Technical Report, 20 p., Cooperative Agreement No. DE-FC26-98FT40320.

Oreopoulou, V., Russ, W. \{eds\} 2007. Utilization of by-products and treatment of waste in the food industry. (Integrating Safety and Environmental Knowledgw into Food Studies Towards Sustainable Development. Springer. Science+ Business Media LLC. 316 p. ISBN-10 0-387-33511-0, Library of Congress Control Number 2006928132.

Papanicolaou, C., 2001. Atlantas ton ellinikon gaianthrakon. Anthrakopetrografikes Parametri. Piotita-Viodiktes. Atlas of Greek Coals, Libr. Inst. of Geol. and Miner. Explor., Athens, Greece, (in Greek), 426 p.

Paredes, M.J., Monteoliva-Sanochez M., Moreno E., Perez J., Ramos-Cormenzana A. and Martinez J. (1986). Effect of waste waters from olive oil extraction plants on the bacterial population of soil, Chemosphere 15: 659-664.

Roig, A., Cayuela, M.L., Sanchez-Monedero, M.A., 2006. An overview on olive mill wastes and their valorization methods. J. Waste Manag. 26: 960-969.

Stepan, D.J., Moe,T.A., Hetland, M.D., Laumb, M.L. 2001. JV -Task 15- Powdered activatedcarbon from North Dakota lignite: An option for disinfection by-product control in water treatment plants. U S.Department of Energy, National Energy Technology Laboratory, Technical Report, 41 p. Cooperative Agreement No. DE-FC26-98FT40321.

Sykorova, I., Pickel, W., Christanis,K., Wolf, m., Taylor, G.H., Flores, D. 2005. Classification of huminite.-ICCP System 1994. Intern. J. of Coal geol. 62 ( 1-2 SPEC.ISS.), PP. 85-106.

Zhang, S., Yan, Y., Yongjie, J. Y., Li, T., Ren, Z., 2005. Upgrading of liquid fuel from the pyrolysis of biomass. Bioresour. Technol. 96, 545-550. 